\title{
Modelling nitrogen, primary production and oxygen in a Mediterranean lagoon. Impact of oysters farming and inputs from the watershed
}

\author{
Annie Chapelle ${ }^{a_{*}}$, Alain Ménesguen ${ }^{a}$, Jean-Marc Deslous-Paoli ${ }^{b}$, Philippe Souchu $^{b}$, \\ Nabila Mazouni ${ }^{b}$, André Vaquer $^{c}$ and Bertrand Millet ${ }^{d}$ \\ aIFREMER DEL Brest, BP 70, 29280 Plouzané, France \\ IFREMER, BP 171, 34203 Sète, France \\ 'Université Montpellier II, Laboratoire d'Hydrologie Marine, Place Eugène Bataillon, 34095 Montpellier Cédex 05, \\ France \\ dUniversité Aix-Marseille II, COM, Station Marine d'Endoume, Rue de la batterie des lions, 13007 Marseille, \\ France \\ *: Corresponding author : Tel.: +33-2-98224356; fax: +33-2-98224548; email: achapel@ifremer.fr
}

\begin{abstract}
An ecosystem model based on nitrogen cycling and oxygen has been developed for the Thau lagoon. It takes into account the specific features of this Mediterranean lagoon, a semi-confined system with watershed inputs and oyster farming. The ecosystem model uses currents calculated by a two-dimensional hydrodynamic model and integrated into a box model. This model is compared with a year survey data and used to estimate nitrogen and oxygen fluxes between the different ecosystem compartments. The yearly simulation shows that the ecosystem behavior is driven by meteorological forcing, especially rain which causes watershed inputs. These inputs trigger microphytoplankton growth, which is responsible for new primary production. During dry periods, nitrogen is recycled into the lagoon thanks to oysters excretion, sediment release, microzooplankton excretion and mineralization. Ammonium produced in this way is consumed by a population of pico- and nanophytoplankton causing regenerated primary production. Consequently, the ecosystem remains highly productive in summer even without external inputs. Shellfish farming also plays an important role in the whole lagoon through biodeposition. Driven by biodeposition, sediment release is the major source of nitrogen in the water column and causes oxygen reduction. The oysters contribute to the recycling activity by excretion, which supports the regenerated primary production. They are also involved in oxygen consumption by respiration which can cause local hypoxia. Further improvements are proposed before this model may become a functional environmental model for a lagoon ecosystem.
\end{abstract}

Keywords: Lagoon ecosystem; Box model; Primary production; Oysters; Nitrogen; Oxygen 


\section{Introduction}

Located on the Mediterranean sea, the Thau lagoon is an important site for oyster production (Crassostrea gigas) with a cultivated production of about 30000 tons per year. It is a shallow lagoon, $19.5 \mathrm{~km}$ long and $4.5 \mathrm{~km}$ wide with a mean depth of $4 \mathrm{~m}$ (Figure 1). The lagoon is almost closed, with only narrow openings toward the sea. Its catchment area is about $300 \mathrm{~km}^{2}$, including agriculture, industrial activities and urban waste. All these activities including aquaculture in the lagoon interfere on the lagoon water quality, sometimes leading to dystrophic crisis called "malaïgue" (Frisoni and Cepja, 1989). A previous program named Ecothau (Amanieu et al., 1989) studied the general ecology of the lagoon. Emphasis was given to a static and empirical description of the spatial and temporal evolution of biological descriptors connected to hydrodynamics through the path analysis technique. As opposed to this previous methodology, the Oxythau program (Deslous-Paoli, 1995) focuses on the interactions between oyster farming areas and the whole lagoon. Five year studies (1991- 1995) were conducted to understand the interactions between oyster culture, water column and sediment and the impact of watershed and meteorological forcing on the whole ecosystem behavior. Deslous-Paoli et al., 1993, raised the problem of sustainable oyster production in the semi-confined Thau lagoon. The modelling approach developed within the Oxythau program intended to describe the dynamics of the lagoon ecosystem, both biological and physical parts. First, different sub-models have been developped to focus on some processes such as the transformation of organic matter in sediment and the nutrients sediment-water exchanges (Chapelle, 1995 ; Chapelle et al., 1994), the influence of wind stress on resuspension (Cugier et al., pers.com.) or the oysters evolution in the lagoon (Bacher et al., 1995). Then, two different methods of coupling hydrodynamics from a 2D hydrodynamical model (Millet, 1989) and nitrogen cycling have been developped and compared (Bacher and Chapelle, accepted). One deals with spatial variability and the influence of meteorological forcing at small spatial scale (Bacher et al, 1997). The other model, which is this paper purpose, focuses on the improvement of the ecosystem description. This model could be considered as a first step in the lagoon ecosystem modelling. The aim of this model is to quantify the dynamic relationships between the different compartments of the lagoon ecosystem like primary production, zooplankton predation, oysters filtration, sediment exchanges and watershed inputs. This study is based on nitrogen cycling related to seasonal variability in a box model of the Thau lagoon.

Figure 1: Location of Thau lagoon

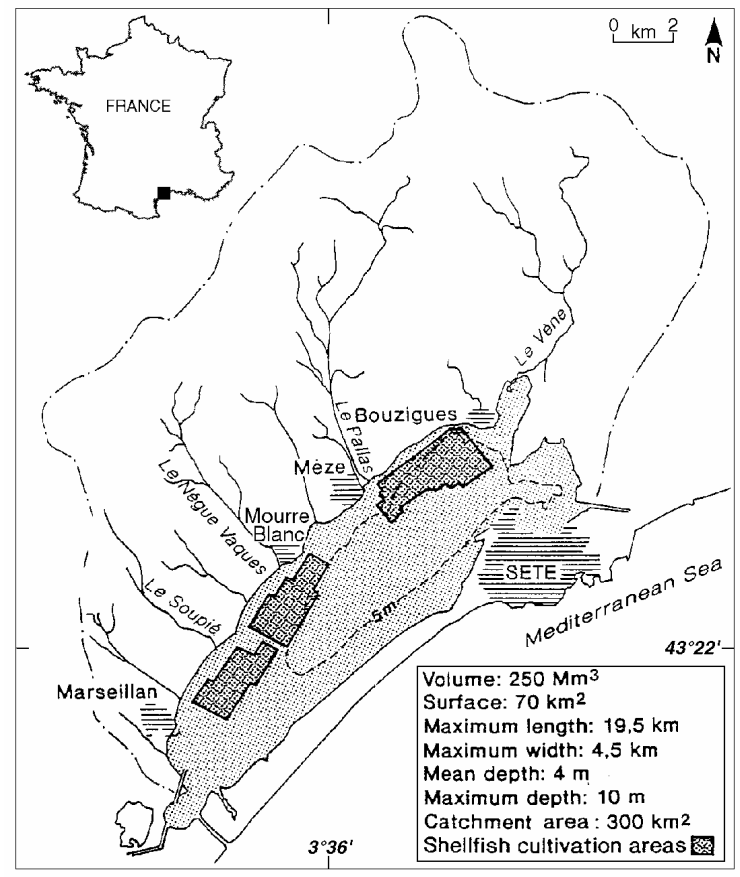




\section{Model description}

\section{Biological framework}

As nitrogen is the limiting nutrient in the Thau lagoon (Picot et al., 1990), the model deals with nitrogen cycling through the different food web steps (Figure 2). Dissolved inorganic nitrogen is split into ammonium (corresponding to the state variable : $\mathbf{N H}_{\mathbf{4}}$ ) and nitrates plus nitrite (corresponding to the state variable : $\mathbf{N O}_{\mathbf{3}}$ ) because their origin in the lagoon are different, $\mathrm{NH}_{4}$ being mostly recycled in the lagoon whereas $\mathrm{NO}_{3}$ is the main form of watershed inputs (Vaulot and Frisoni, 1986). Dissolved nitrogen is expressed in mmol. $\mathrm{m}^{-3}$.

Figure 2 : Conceptual diagram of the thau lagoon ecosystem model.

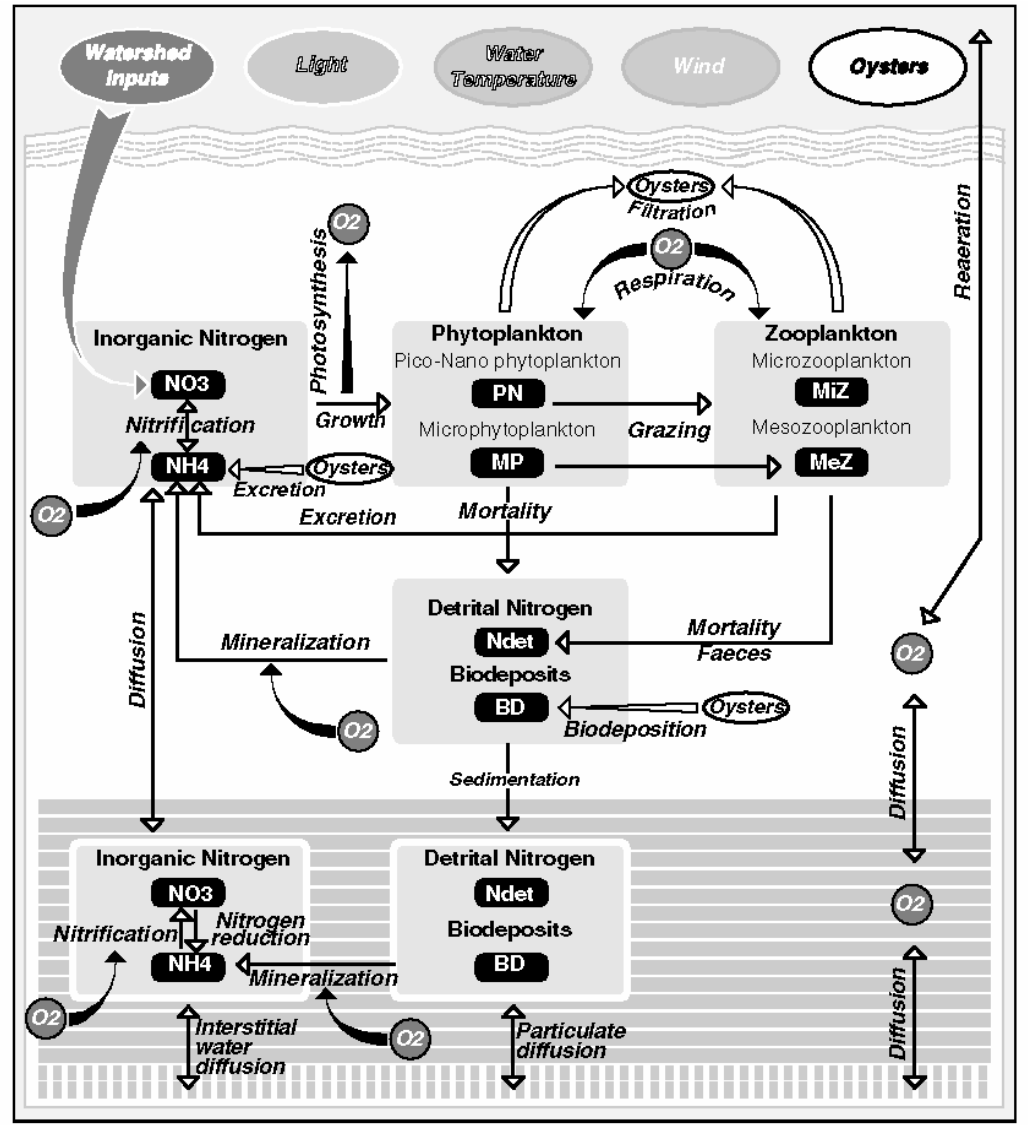

The model takes into account two types of phytoplankton, the small species $(<20 \mu$; PN) including picophytoplankton and nanophytoplankton and the larger species, the microphytoplankton $(20-200 \mu$; MP). Dynamics of these two groups are different. Piconanophytoplankton are dominant most of time in the lagoon (Courties et al., 1994 ; ChrétiennotDinet et al., 1995) but microphytoplankton grow particulary after rainy events. Each group has different nitrogen assimilation kinetics (Collos et al., 1997) and predators. Considering a Chloa/ $\mathrm{N}$ ratio of 1g/mol (Eppley et al., 1971), phytoplankton concentration can be expressed in $\mathrm{mg}$ Chloa. $\mathrm{m}^{-3}$ as measurements.

Phytoplankton predation is simulated by two groups of zooplankton, microzooplankton

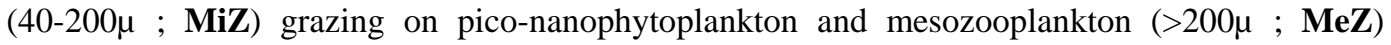
grazing on pico-nanophytoplankton, microphytoplankton and microzooplankton (Cirillo, 1994 ; Lam-Hoai et al., 1997 ; Rougier and Lam-Hoai, 1997). These organisms play also an important role in nitrogen recycling by ammonium excretion (Azam et al., 1983). Considering that nitrogen corresponds to $10 \%$ of the zooplankton dry weight and that dry weight corresponds to $13 \%$ of the 
wet weight (Lam-Hoai, 1994) zooplankton can be expressed in $\mu \mathrm{g} . \mathrm{m}^{-3}$ of wet weight, which is the measurement unit.

Ndet represents the detritus pool resulting from phytoplankton and zooplankton mortality and zooplankton feces. Biodeposits (BD) represent the oysters feces and pseudofeces. Ndet and BD correspond to the detrital organic matter, expressed in mmol. $\mathrm{m}^{-3}$.

To study the oxygen and the occurence of hypoxia events, we model dissolved oxygen $\left(\mathbf{O}_{2}\right)$ in $\mathrm{gO}_{2} \cdot \mathrm{m}^{-3}$. Dissolved oxygen concentration depends on reaeration at sea-surface, consumption through respiration of phytoplankton, zooplankton and oysters, mineralization of organic matter, nitrification and production by phytoplankton photosynthesis.

Nitrogen cycling and oxygen are simulated into the sediment. $\mathbf{N H}_{\mathbf{4}}, \mathbf{N O}_{\mathbf{3}}$ and $\mathbf{O}_{\mathbf{2}}$ are dissolved in the interstitial water, Ndet and BD correspond to the particulate organic matter.

The cultivated filter-feeders play an important part in nitrogen cycling though they are not represented as a true compartment. In fact, we consider that their biomass (calculated from measurements in the three shellfish culture areas - Hamon et Tournier, 1990 -) is almost stable over the year and can be described as a forcing function in the model. Filter feeders act on nitrogen cycling in different ways, either as a sink, filtration, or a source, excretion and biodeposition. They also cause oxygen sink by respiration. These processes are deduced from measurements by metabolic enclosures (Mazouni, 1995 ; Mazouni et al.,1998) and include the effect of oysters plus epibiota.

Another driving variable is nutrient inputs from the watershed. Since river inputs are irregular and little, we do not simulate water discharge but nitrogen inputs. To simulate daily nitrogen inputs, we multiply the annual nitrogen input estimated by Pichot et al. (1994), by the daily percentage of rain (meteofrance data). As the estimation of ammonium or nitrate inputs are not well known, we consider that all nitrogen inputs from watershed are nitrates, following Pichot et al., 1994.

Other driving variables are light, wind and temperature. Light, wind direction and wind intensity were measured daily, water temperature is given by in situ weekly measurements.

\section{$\underline{\text { Equations and parameters }}$}

Phytoplankton growth $(\mu)$ is function of light $f(I)$, temperature $f(T)$ and dissolved nitrogen $\mathrm{f}(\mathrm{N}): \mu=\mu_{\max } \times f(\mathrm{I}) \times \mathrm{f}(\mathrm{N}) \times \mathrm{f}(\mathrm{T}) \quad$ where $\mu_{\max }$ is the maximum daily growth rate $\left(\mathrm{d}^{-1}\right)$.

Light function is described by a modified Steele formula (Steele, 1962) without photoinhibition where $\mathrm{I}_{\mathrm{opt}}$ is the optimum light. Experiments have shown that phytoplankton from the Thau lagoon do not exhibit photoinhibition even during high light exposure (Collos et al., 1997 ; Vaquer et al., 1996) :

$f(I)=\frac{1}{24} \int_{0}^{24} \frac{1}{Z} \int_{0}^{z_{\max }} \frac{\mathrm{I}}{\mathrm{I}_{\mathrm{opt}}} \times \mathrm{e}^{\left(1-\frac{\mathrm{I}}{\mathrm{I}_{\mathrm{opt}}}\right)} \times \mathrm{dz} \times \mathrm{dt} \quad$ for $\mathrm{I}<\mathrm{I}_{\text {opt }} \quad$ and $\quad \mathrm{f}(\mathrm{I})=1 \quad$ for $\mathrm{I}>\mathrm{I}_{\text {opt }}$

Light function is hourly calculated and integrated over the depth $\left(\mathrm{z}_{\max }\right)$.

$\mathrm{I}$ is the light intensity at depth $\mathrm{z}$ calculated from the light surface intensity (Is) and the extinction coefficient (equal to $\left.4 \mathrm{~m}^{-1}\right) . \mathrm{I}=\mathrm{I}_{\mathrm{S}} \times \mathrm{e}^{(-0.4 \times \mathrm{z})}$

Temperature function is : $\mathrm{f}(\mathrm{T})=\mathrm{e}^{\mathrm{k}_{\mathrm{T}} \times \mathrm{T}}$

derived from Eppley (1972),

$\mathrm{k}_{\mathrm{T}}\left({ }^{\circ} \mathrm{C}^{-1}\right)$ corresponds to a $\mathrm{Q}_{10}=2$.

Dissolved nitrogen controls phytoplankton growth. Small algae show a preference for ammonium while big diatoms grow especially on nitrate (Collos et al., 1997). Following this, we use the Wroblewski formula (1977) for pico-nanophytoplankton wich describes a inhibition of $\mathrm{NO}_{3}$ uptake by $\mathrm{NH}_{4}: \mathrm{f}(\mathrm{N})=\frac{\mathbf{N O}_{3}}{\mathbf{N O}_{3}+\mathrm{K}_{\mathrm{N}}} \times \mathrm{e}^{-\psi \times \mathbf{N H}_{4}}+\frac{\mathbf{N H}_{\mathbf{4}}}{\mathbf{N H}_{\mathbf{4}}+\mathrm{K}_{\mathrm{N}}}$

$\mathrm{K}_{\mathrm{N}}$ is the half saturation constants for nitrogen uptake and $\psi$ the inhibitor factor.

For microphytoplankton we use a Michaelis-Menten formula : $f(N)=\frac{\mathbf{N O}_{\mathbf{3}}+\mathbf{N H}_{\mathbf{4}}}{\mathbf{N O}_{\mathbf{3}}+\mathbf{N H}_{\mathbf{4}}+\mathrm{K}_{\mathrm{N}}}$

with $\mathrm{K}_{\mathrm{N}}$ the half saturation constant for nitrogen uptake.

$\mathrm{NH}_{4}$ uptake and $\mathrm{NO}_{3}$ uptake are resumed by : 


$$
\begin{aligned}
& \mathrm{upt}_{\mathrm{NH} 4}=\mu_{\mathrm{PN}} \times\left(\frac{\mathrm{NH}_{4}}{\mathrm{NH}_{4}+\mathrm{K}_{\mathrm{N}}} / \mathrm{f}(\mathrm{N})_{\mathrm{PN}}\right) \times \mathrm{PN}+\mu_{\mathrm{MP}} \times \frac{\mathrm{NH}_{4}}{\mathrm{NH}_{4}+\mathrm{NO}_{3}} \times \mathrm{MP} \\
& \mathrm{upt}_{\mathrm{NO} 3}=\mu_{\mathrm{PN}} \times\left(\frac{\mathrm{NO}_{3}}{\mathrm{NO}_{3}+\mathrm{K}_{\mathrm{N}}} \times \mathrm{e}^{-\psi \times N H_{4}} / \mathrm{f}(\mathrm{N})_{\mathrm{PN}}\right) \times \mathrm{PN}+\mu_{\mathrm{MP}} \times \frac{\mathrm{NO}_{3}}{\mathrm{NH}_{4}+\mathrm{NO}_{3}} \times \mathrm{MP}
\end{aligned}
$$

The Ivlev formula depicts zooplankton grazing (Ivlev, 1955):

$\left.g=g_{\max } \times f(T) \times\left(1-e^{-K_{1} \times \max (0, \text { Phy-Phy }}\right)\right)$ with $g_{\max }$ the maximum grazing rate, $K_{I}$ the Ivlev constant, Phy, the total biomass of prey and Phy 0 a threshold value. $f(T)$ is the same function as for phytoplankton.

For microzooplankton the prey correspond to pico-nanophytoplankton, for mesozooplankton the preys are described as the sum of possible preys weighted by a grazing efficiency coefficient (eff) between 0 and 1 :

$$
\text { Phy }=\mathrm{PN} \times \mathrm{eff}_{\mathrm{PN}}+\mathrm{MP} \times \mathrm{eff}_{\mathrm{MP}}+\mathrm{MiZ} \times \mathrm{eff}_{\mathrm{MiZ}}
$$

Assimilation (ass) is a constant percentage of grazing (Conover, 1966 ; Butler et al., 1969).

Phytoplankton and zooplankton mortality (death) are function of temperature according to the Eppley formula : death $=$ death $_{\max } \mathrm{x} f(\mathrm{~T})$ with death max $_{\max }$ the maximum daily mortality rate $\left(\mathrm{d}^{-1}\right)$ at $0^{\circ} \mathrm{C}$.

Zooplankton excretion is a linear function of grazing (Goldman and Caron, 1985 ; Verity 1985 ) with a minimal rate of excretion, excr $_{\min }$, depending on temperature according a $\mathrm{Q}_{10}=2$ (Wen and Peters, 1994) : excrzoo $=\max \left(g \times\right.$ excr $_{\%}$, excr $\left._{\min } \times f(T)\right)\left(d^{-1}\right)$

Parameters values are different for the two groups of zooplanton (Table2).

In the water column, nitrogen mineralization and nitrification are function of temperature and dissolved oxygen (Nankanashi et al., 1986 ; Henriksen and Kemp, 1988) :

$$
\min N=\min _{0} \times f(T) \times \frac{\mathrm{O}_{2}}{\mathrm{O}_{2}+\mathrm{K}_{\min }} \quad\left(\mathrm{d}^{-1}\right) \quad \text { nit }=\text { nit }_{0} \times f(T) \times \frac{\mathrm{O}_{2}}{\mathrm{O}_{2}+\mathrm{K}_{\text {nit }}} \quad\left(\mathrm{d}^{-1}\right)
$$

$\min _{0}$ and nit $t_{0}$ are daily rates of mineralization and nitrification at $0^{\circ} \mathrm{C}$ and $\mathrm{K}_{\min }$ and $\mathrm{K}_{\text {nit }}$ the half saturation constants in $\mathrm{gO}_{2} \cdot \mathrm{m}^{-3}$.

Oyster filtration, which represents the filtration of oysters plus epibiota, is function of total oyster biomass (Oybiomass) and temperature (Deslous-Paoli and Vaquer, 1995 ; Mazouni et al., 1997) : $\quad$ filt $=$ filt $_{0} \times \mathrm{e}^{\left(\mathrm{k}_{\mathrm{T}} \times \mathrm{T}\right)} \times$ Oybiomass $\quad\left(\mathrm{d}^{-1}\right)$

filt $t_{0}$ is the daily filtration rate at $0^{\circ} \mathrm{C}$.

The group of oysters plus epibiota has a grazing efficiency (effO) for each prey, corresponding to the prey size (Mazouni et al., 1997). So total predation of oysters is the sum of each :

pred $=$ filt $\times\left(\mathrm{PN} \times\right.$ effO $_{\mathrm{PN}}+\mathrm{MP} \times$ effO $_{\mathrm{MP}}+\mathrm{MiZ} \times$ effO $_{\mathrm{MiZ}}+\mathrm{MeZ} \times$ effO $\left._{\mathrm{MeZ}}+\mathrm{Ndet} \times \mathrm{effO}_{\mathrm{Ndet}}\right)$

Oyster excretion is function of temperature (Mazouni et al., 1998) :

Oyexcr $=$ excr $_{0 y} \times \mathrm{e}^{\left(\mathrm{ke}_{\mathrm{T}} \times \mathrm{T}\right)} \times \mathrm{O}$ ybiomass, with $\mathrm{excr}_{\mathrm{Oy}}$, being the daily excretion rate at $\mathrm{O}^{\circ} \mathrm{C}$ $\left(\mathrm{gO}_{2} \cdot \mathrm{d}^{-1} \cdot \mathrm{gDW}^{-1}\right)$, and $\mathrm{ke}_{\mathrm{T}}$ the temperature coefficient for oyster excretion $\left({ }^{\circ} \mathrm{C}^{-1}\right)$.

Biodeposition is a constant percentage of predation (Mazouni, 1995).

In sediment, mineralization and nitrification are the same as in water. Denitrification occurs when oxygen is low : denit $=$ denit $_{0} \times f(T) \times\left(1-\frac{\mathrm{O}_{2}}{\mathrm{O}_{2}+\mathrm{K}_{\text {nit }}}\right)$ (Chapelle, 1995) where denit $_{0}$ is the daily denitrification rate at $\mathrm{O}^{\circ} \mathrm{C}$.

To simulate the oxygen evolution we take into account production by phytoplankton photosynthesis, exchange with the atmosphere at sea-surface, consumption by mineralization, nitrification and respiration.

Oxygen photosynthesis is function of phytoplankton growth :

photos $=\mathrm{Q}_{\mathrm{PS}} \times \mathrm{R}_{\mathrm{PS}} \times\left(\mu_{\mathrm{PN}} \times \mathrm{PN}+\mu_{\mathrm{MP}} \times \mathrm{MP}\right) \quad \mathrm{Q}_{\mathrm{PS}}$ is the photosynthetic ratio (dimensionless) and $\mathrm{R}_{\mathrm{PS}}$ the stoechiometric ratio $\left(\mathrm{gO}_{2} / \mathrm{mmolN}\right)$ bewteen $\mathrm{O}_{2}$ produced and organic nitrogen synthetized following the equation :

$106 \mathrm{CO}_{2}+106 \mathrm{H}_{2} \mathrm{O}+16 \mathrm{NH}_{3}+\mathrm{H}_{3} \mathrm{PO}_{4} \rightarrow\left(\mathrm{CH}_{2} \mathrm{O}\right)_{106}\left(\mathrm{NH}_{3}\right)_{16}\left(\mathrm{H}_{3} \mathrm{PO}_{4}\right)+106 \mathrm{O}_{2}$

Respiration of phytoplankton and zooplankton are function of temperature, same as primary production. Oyster respiration is calculated from the excretion and is temperature dependant (Mazouni et al., 1998). 
Consumption by mineralization and nitrification are inferred from the stochiometric ratio between $\mathrm{N}$ and $\mathrm{O}_{2}$ in organic matter, following the reaction :

$\left(\mathrm{CH}_{2} \mathrm{O}\right)_{106}\left(\mathrm{NH}_{3}\right)_{16}\left(\mathrm{H}_{3} \mathrm{PO}_{4}\right)+106 \mathrm{O}_{2} \rightarrow 106 \mathrm{CO}_{2}+106 \mathrm{H}_{2} \mathrm{O}+16 \mathrm{NH}_{3}+\mathrm{H}_{3} \mathrm{PO}_{4}$

Resulting from this reaction, $0.212 \mathrm{gO} 2$ is consumed for $1 \mathrm{mmol} \mathrm{N}$ mineralized and the equation is: omin $=0.212 * \operatorname{minN} *(\mathrm{Ndet}+\mathrm{BD})$

Nitrification follows the formula : $\mathrm{NH}_{4}+2 \mathrm{O}_{2} \rightarrow \mathrm{NO}_{3}+\mathrm{H}_{2} \mathrm{O}+\mathrm{H}^{+}$

with $0.064 \mathrm{gO}_{2} / \mathrm{mmolN}$ is consummed. The nitrification process is : onit $=0.064 * \mathrm{NH} 4 *$ nit

Exchange at sea-surface depends on the gradient between dissolved oxygen concentration and saturating oxygen in water $\left(\mathrm{O}_{2 \text { sat }}\right)$ which is calculated with temperature and salinity, from Aminot and Chaussepied (1983) : oair $=\left(\mathrm{O}_{2 \text { sat }}-\mathrm{O}_{2}\right) \times$ reaeration

Reaeration $\left(\mathrm{d}^{-1}\right)$ is the daily exchange rate of oxygen at sea-surface, which depends on wind speed (ws in mph which has to be converted into $\mathrm{m}^{-\mathrm{d}^{-1}}$ ) and water depth (m) according to the relation of Riley and Stefan (1988) :

reaeration $=\frac{0.641+0.0256 \times(\mathrm{ws} / 0.0447)^{2}}{\text { depth }}$

The whole system of equations is presented in Table 1 and the parameter values in Table 2.

Table 1 : System of differential equations

Ammonium in water column

$\frac{\mathrm{dNH}_{\mathbf{4}}}{\mathrm{dt}}=\min \mathrm{N} \times(\mathbf{N d e t}+\mathbf{B D})-\mathrm{upt}_{\mathrm{NH} 4}+$ Oyexcr + excrMiZ $\times \mathbf{M i Z}+\operatorname{excrMeZ} \times \mathbf{M e Z}-\mathrm{nit} \times \mathbf{N H}_{\mathbf{4}}$

Nitrate in water column

$\frac{\mathrm{dNO}_{3}}{\mathrm{dt}}=$ nit $\times \mathbf{N H}_{\mathbf{4}}-\mathrm{upt}_{\mathrm{NO} 3}+$ Ninput - Nouput

Pico-nanophytoplankton

$\frac{\mathrm{dPN}}{\mathrm{dt}}=\left(\mu_{\mathrm{PN}}-\mathrm{d}_{\mathrm{PN}}-\right.$ filt $\left.\times \mathrm{effO}_{\mathrm{PN}}\right) \times \mathbf{P N}-\mathrm{g}_{\mathrm{MiZ}} \times \mathbf{M i Z}-\mathrm{g}_{\mathrm{MeZ}} \times \mathbf{M e Z} \times \frac{\text { eff }_{\mathrm{PN}}}{\text { Phy }}$

Microphytoplankton

$\frac{\mathrm{d} \mathbf{M P}}{\mathrm{dt}}=\left(\mu_{\mathrm{MP}}-\mathrm{d}_{\mathrm{MP}}-\right.$ filt $\left.\times \mathrm{effO}_{\mathrm{MP}}-\mathrm{g}_{\mathrm{MeZ}} \times \mathbf{M e Z} \times \frac{\text { effMP }}{\text { Phy }}\right) \times \mathbf{M P}$

Microzooplancton

$\frac{\mathrm{d} \mathbf{M i Z}}{\mathrm{dt}}=\left(\right.$ ass $_{\mathrm{MiZ}} \times \mathrm{g}_{\mathrm{MiZ}}-\mathrm{d}_{\mathrm{MiZ}}-\operatorname{excr}_{\mathrm{MiZ}}-$ filt $\left.\times \operatorname{effO}_{\mathrm{MiZ}}-\mathrm{g}_{\mathrm{MeZ}} \times \mathbf{M e Z} \times \frac{\operatorname{eff}_{\mathrm{MiZ}}}{\text { Phy }}\right) \times \mathbf{M i Z}$

Mesozooplancton

$\frac{\mathrm{d} \mathbf{M e Z}}{\mathrm{dt}}=\left(\right.$ ass $_{\mathrm{MeZ}} \times \mathrm{g}_{\mathrm{MeZ}}-\mathrm{d}_{\mathrm{MeZ}}-$ excr $_{\mathrm{MeZ}}-$ filt $\left.\times \operatorname{effO}_{\mathrm{MeZ}}\right) \times \mathbf{M e Z}$

Detrital Nitrogen in water column

$\frac{\mathrm{dNdet}}{\mathrm{dt}}=(-\min \mathrm{N}-$ filt $\times$ effO $\mathrm{Ndet}) \times \mathbf{N d e t}+\mathrm{d}_{\mathrm{PN}} \times \mathbf{P N}+\mathrm{d}_{\mathrm{MP}} \times \mathbf{M P}$

$+\left(\mathrm{d}_{\mathrm{MiZ}}+\left(1-\right.\right.$ ass $\left.\left._{\mathrm{MiZ}}\right) \times \mathrm{g}_{\mathrm{MiZ}}\right) \times \mathbf{M i Z}+\left(\mathrm{d}_{\mathrm{MeZ}}+\left(1-\right.\right.$ ass $\left.\left._{\mathrm{MeZ}}\right) \times \mathrm{g}_{\mathrm{MeZ}}\right) \times \mathbf{M e Z}$

Biodeposit in water column

$\frac{\mathrm{d} \mathbf{B D}}{\mathrm{dt}}=\mathrm{bd}_{\%} \times$ pred $-\min \mathrm{N} \times \mathbf{B D}$

Dissolved oxygen in water column

$\frac{\mathrm{d} \mathbf{O}_{2}}{\mathrm{dt}}=$ photos + oair - respzoo - respphy - respoyst - o min - onit

Ammonium in sediment

$\frac{\mathrm{dNH}_{\mathbf{4}}}{\mathrm{dt}}=\min \mathrm{N} \times(\mathbf{N d e t}+\mathbf{B D}) \times \frac{\text { pvol }}{\text { ivol }}-$ nit $\times \mathbf{N H}_{\mathbf{4}}+$ denit $\times \mathbf{N O}_{\mathbf{3}}$

Nitrate in sediment

$\frac{\mathrm{dNO}_{3}}{\mathrm{dt}}=$ nit $\times \mathbf{N H}_{\mathbf{4}}-$ denit $\times \mathbf{N O}_{3}$ 
Detrital Nitrogen in sediment $\frac{\mathrm{dNdet}}{\mathrm{dt}}=-\min \mathrm{N} \times \mathbf{N d e t}$

Biodeposits in sediment $\frac{\mathrm{d} \mathbf{B D}}{\mathrm{dt}}=-\min \mathrm{N} \times \mathbf{B D}$

Dissolved oxygen in sediment $\frac{\mathrm{d} \mathbf{O}_{2}}{\mathrm{dt}}=-\mathrm{o}$ min - onit 
Table 2 List of parameters

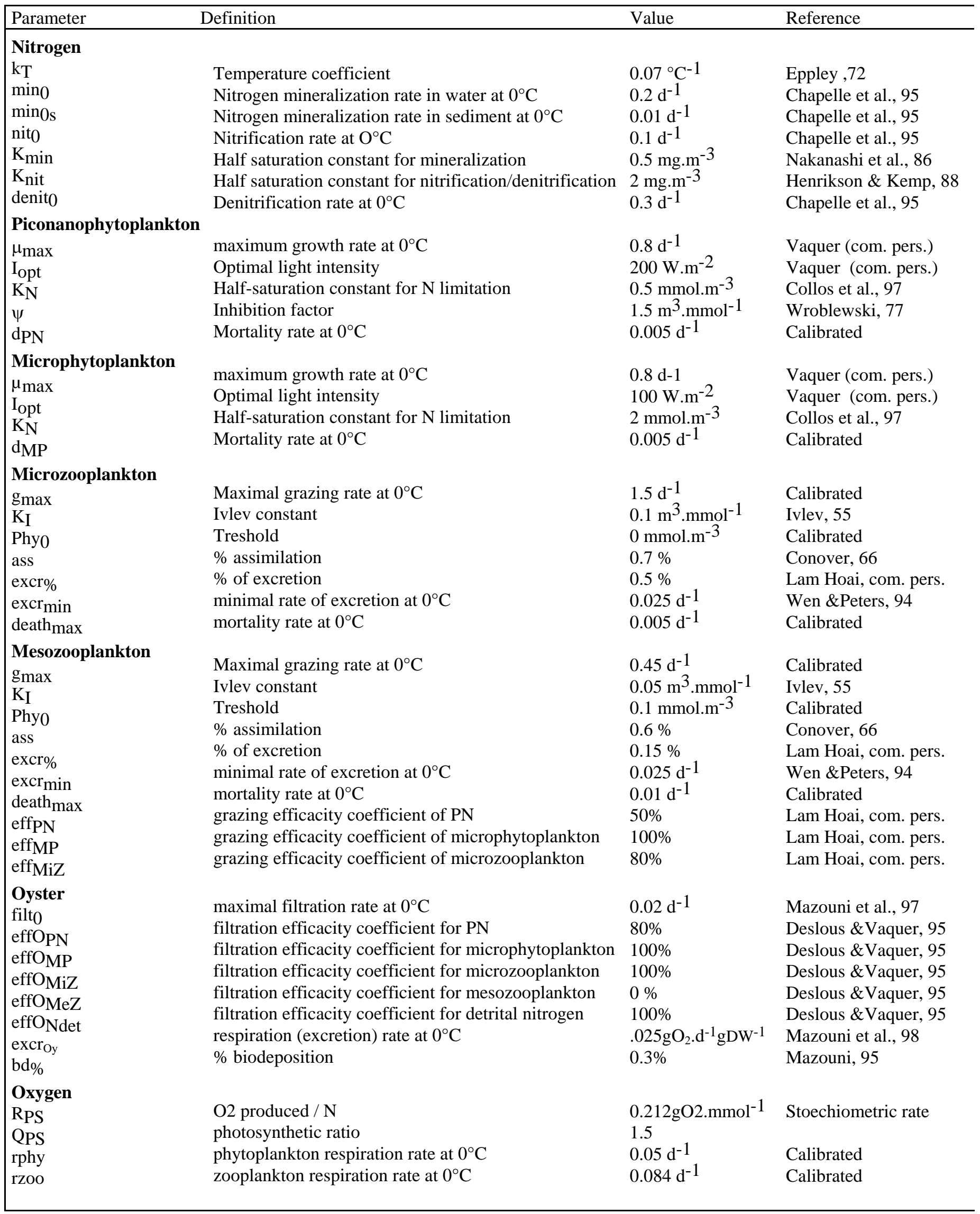


Box model

Hydrodynamics of the lagoon have been already studied, enlightening the importance of the physics in the spatial distribution of the ecological variables (Jarry et al., 1990 ; Jouffre et al., 1991 ; Picot et al. 1990). As the biological complexity (9 state variables) and the simulation length (a year) are high, we choose to couple the biological sub-model not directly to an hydrodynamic model but to a box model in order to shorten daily calculations. A twodimensional model gives the advection field according to a spatial discretization of $250 \mathrm{~m}$ in the two horizontal directions (Millet, 1989). The tidal currents are negligible compared to the currents generated by the wind. Wind statistics showed that $40 \%$ of the wind directions are from the North-West, $13 \%$ from the North, $11 \%$ from the West and that $70 \%$ of the wind speeds lie between 2 and $8 \mathrm{~m} . \mathrm{s}^{-1}$. So the hydrodynamic model has been applied to four cases corresponding to the more frequent wind directions, $45^{\circ}, 110^{\circ}, 265^{\circ}$ and $325^{\circ}$. To simulate the hydrodynamics during a real year thanks to only four wind cases, we use, each day, the case the real wind direction is closer to and we modulate the current velocities proportionnally to the measured wind speed.

To reproduce spatial heterogeneity, the lagoon is divided into ten water boxes (Figure 3). The three oyster culture areas are joined in two boxes, (grey boxes in figure 3). North and east boxes ( 6 boxes) receive the watershed inputs. As sea exchanges are very limited, they are not simulated at this moment. Each box is homogeneous and contains several physical cells. Under each water box we take into account three sediment boxes corresponding to the three layers 0-1 $\mathrm{cm}, 1-2 \mathrm{~cm}$ and 2-10 $\mathrm{cm}$ in order to model the oxygen characteristics - sediment surface layer being oxic and the deeper one being anoxic. Therefore, total number of boxes is 40 .

ELISE, an interactive software (Ménesguen, 1991), calculates the exchanges between water boxes according to the fine grid current fields, by adding all the advective fluxes between two adjacent boxes. A empirical diffusion coefficient is used to described vertical exchanges within the sediment and between sediment and water column (Chapelle, 1995 ; Chapelle et al., 1994). Resuspension is neglected in the Thau lagoon because of the relative high depth (Cugier et al., pers. com.).

Time step used for simulation is 0.1 day and results are shown each day at noon.

Figure 3 : Box model. Current field and box exchanges for a $110^{\circ}$ wind.

(grey boxes are shellfish farming boxes)

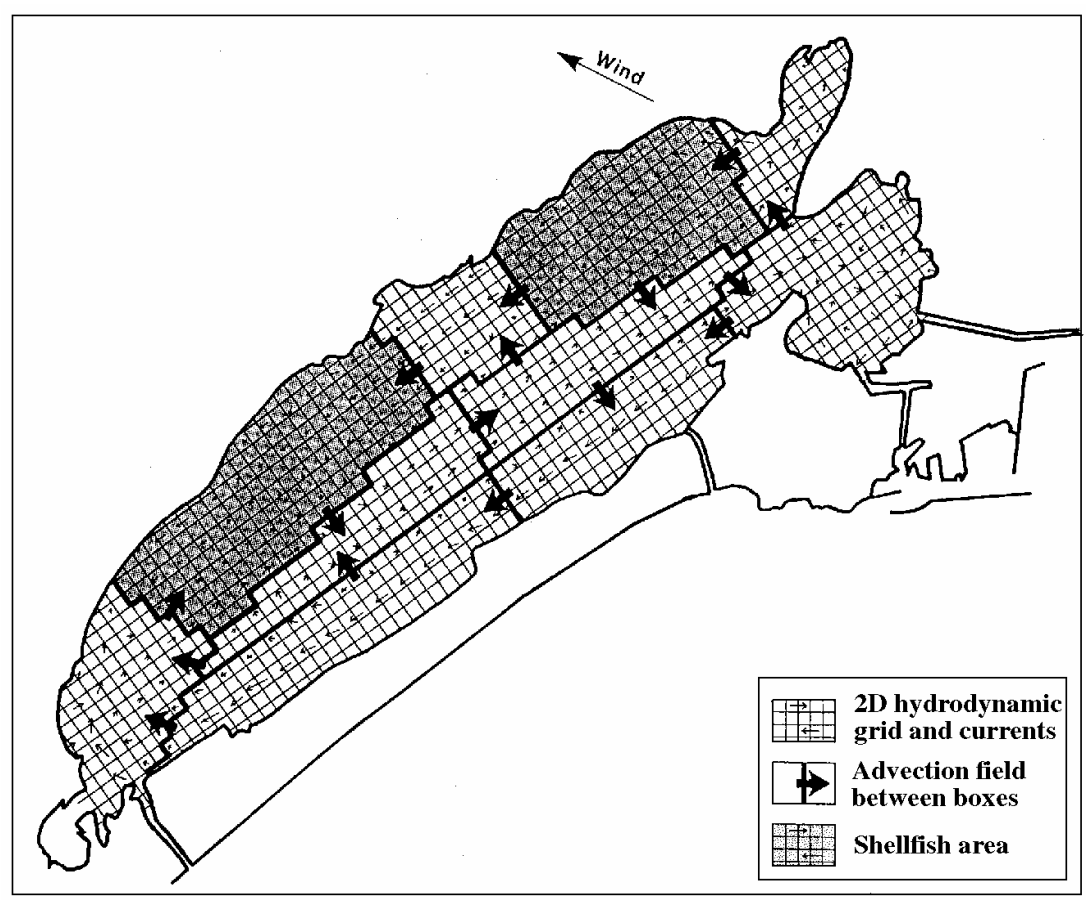




\section{Results}

Simulation of the 1993 year

The model is run with ELISE software for the year 1993. This year was sampled weekly or fortnightly within the Oxythau program. Figure 4 gives some simulation results compared to in situ data (Deslous \& Vaquer, 1995) for a shellfish box.

Figure 4 : Simulated $(-)$ and observed $(\bullet)$ values during the year 1993 for an oyster box
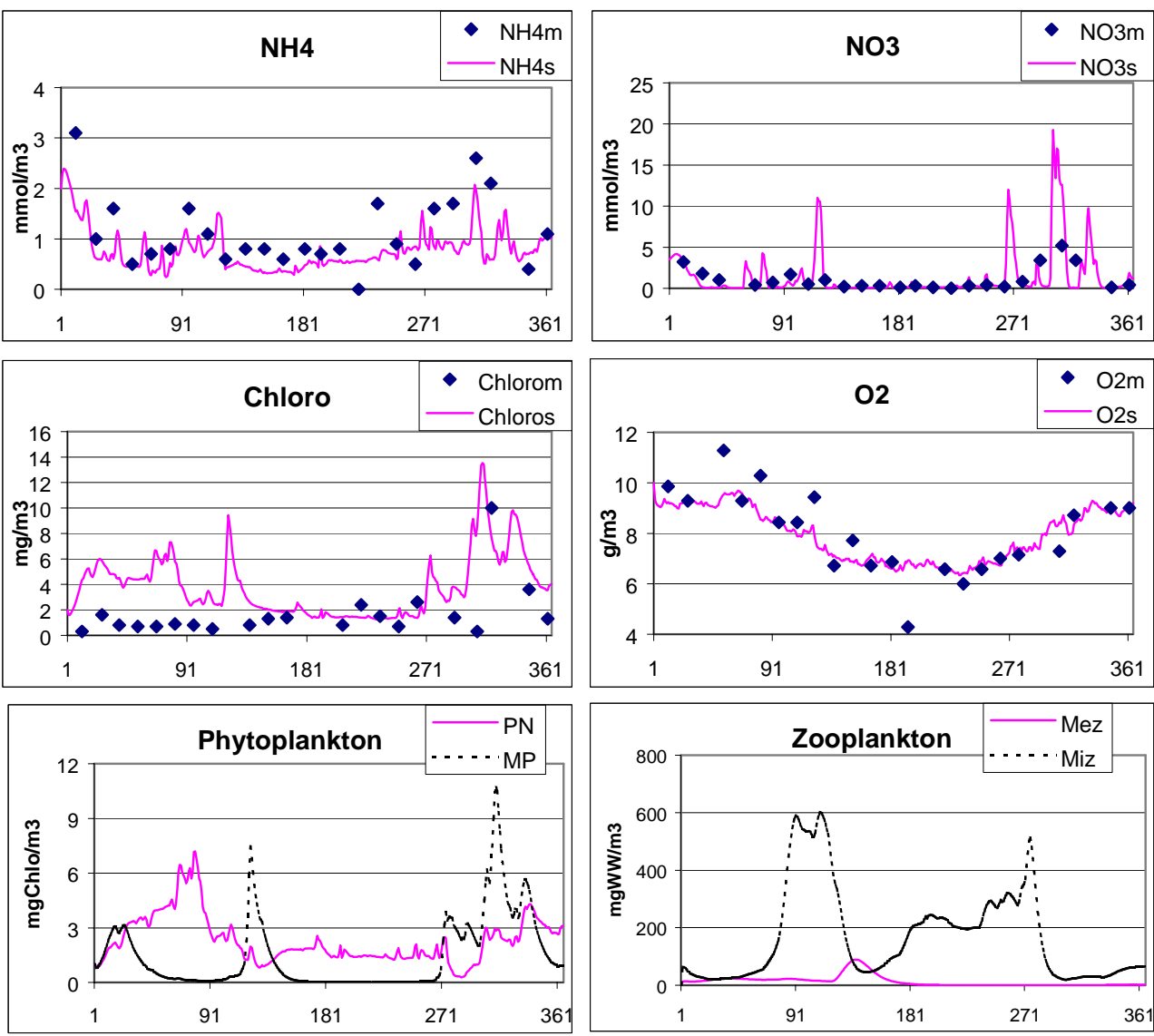

Simulated ammonium never exceeds $2.5 \mathrm{mmol} . \mathrm{m}^{-3}$ while simulated nitrate has very variable concentrations from nearly 0 to $20 \mathrm{mmol} . \mathrm{m}^{-3}$. The high nitrate concentrations occur especially during spring and autumn while, in summer, ammonium is more abundant than nitrate. Compared to the measurements, the model underestimates ammonium in autumn and, on the contrary, shows overestimated nitrate spikes at the same period. Different explanations may be given to understand this discrepancy. First, measurements are made each week and it is possible that data do not catch the maximum nitrate concentration in the lagoon. Another possibility is that we consider that all watershed inputs are nitrate while urban wastes rather provide ammonium. The last explanantion may be that inputs from watershed are delayed into the model boxes more than in a river plume.

Microphytoplankton grows in winter, spring and autumn. In automn the bloom reaches more than $10 \mathrm{mg}$ Chloa. $\mathrm{m}^{-3}$. On the contrary, pico-nanophytoplankton are more stable the whole year long, with maxima in winter and autumn which do not exceed $8 \mathrm{mg}$ Chloa. $\mathrm{m}^{-3}$. In summer, microphytoplantkon biomass is negligible and piconanophytoplankton are dominant. We can only compare the simulated chlorophyll which corresponds to picoplankton plus microplankton with chlorophyll data. Then, the model shows the same big autumnal bloom but overestimates chlorophyll in winter. 
Microzooplankton grow during spring and summer and reach $600 \mathrm{mg} \cdot \mathrm{m}^{-3}$ fresh weight. Mesozooplankton show a first development in spring after the microphytoplankton spring bloom, but decrease drastically afterwards. Rougier and Lam-Hoai measurements (1997) give smaller concentrations for the year 1994 (no measurements in 1993), with maximum microzooplankton biomass around $50 \mathrm{mg} \cdot \mathrm{m}^{-3}$ fresh weight and the same for mesozooplankton. Following this comparison, even if simulation and data do not correspond to the same year, we can conclude that the model may overestimate microzooplankton and underestimate mesozooplankton. In consequence, it will be necessary to improve this trophic level in the model.

Anyway in term of nitrogen, the ratio of piconanophytoplankton/microzooplankton corresponds to $10 / 1$ which is quite realistic (600mg WW/5mgChloa).

In sediments, ammonium is the major form of nitrogen in interstitial water. Simulated concentrations are between 40 and $50 \mathrm{mmol} . \mathrm{m}^{-3}$ in summer and $50-60$ mmol.m $\mathrm{m}^{-3}$ in winter. We can compare them to in situ data (Table 3). In summer, the centrifugation method is uncertain because of the sediment structure and simulation results agree with measurements with diffusion membranes (Mesnage et al., 1993). Winter simulated results agree with the range of data obtained by both methods.

Table 3 : Dissolved nitrogen measured in interstitial water $\left(\mathrm{mmol} . \mathrm{m}^{-3}\right)$

a : by diffusion membranes (Mesnage, 1994)

b : by centrifugation (Deslous-Paoli et al., 1991)

\begin{tabular}{|c|c|c|c|c|c|}
\hline & \multicolumn{2}{|c|}{ Summer } & \multicolumn{2}{|c|}{ Winter } \\
\hline & & & b & $\mathrm{a}$ & b \\
\hline \multirow{3}{*}{$\mathrm{NH}_{4}$} & $0-1 \mathrm{~cm}$ & 40 & $267-537$ & 100 & $33-40$ \\
\hline & $1-2 \mathrm{~cm}$ & 60 & $412-495$ & 120 & $55-58$ \\
\hline & $2-8 \mathrm{~cm}$ & 80 & $119-258$ & 150 & $51-61$ \\
\hline \multirow{3}{*}{$\mathrm{NO}_{3}$} & $0-1 \mathrm{~cm}$ & & $0.3-0.7$ & & $0.25-0.6$ \\
\hline & $1-2 \mathrm{~cm}$ & & $0.3-0.6$ & & $0.2-0.3$ \\
\hline & $2-8 \mathrm{~cm}$ & & $0.2-0.4$ & & $0.2-0.55$ \\
\hline
\end{tabular}

Oxygen evolution in the water column shows a minimum in summer in the model and in data (Souchu et al., 1997). This summer mininum can be explained by the oxygen solubility decrease at high temperature and by an increase of mineralization, nitrification and organism respiration. In the first centimetres of sediment, oxygen concentrations are much lower than in the water column particularly under the shellfish areas. Other boxes remain oxic during almost the whole year. Deeper sediment is anoxic.

Even though the annual evolution is similar between boxes of the lagoon, Figure 5 shows the spatial distribution of some simulated variables for the two periods, summer with no rain, and rainy autumn.

Ammonium concentration is greater in shellfish areas, especially in summer, where it is three times higher. On the contrary, phytoplankton concentration (piconano + microphytoplankton) is minimum in the shellfish boxes. This corresponds to measurements, which give chlorophyll concentrations lower in shellfish areas than elsewhere, to an extent of $0.3 \mathrm{mg}$ Chlo.m ${ }^{-3}$ in winter to $10 \mathrm{mg}$ Chlo. $\mathrm{m}^{-3}$ during diatom blooms (Souchu, accepted). In shellfish areas microzooplankton is more than three times less abundant, corresponding to Rougier and Lam-Hoai observations (1997).

For dissolved oxygen, the spatial results show also differences between shellfish culture areas where concentrations are smaller than in the rest of the lagoon. 
Figure 5 : Spatial results of the simulation for two periods : dry summer and rainy autumn.
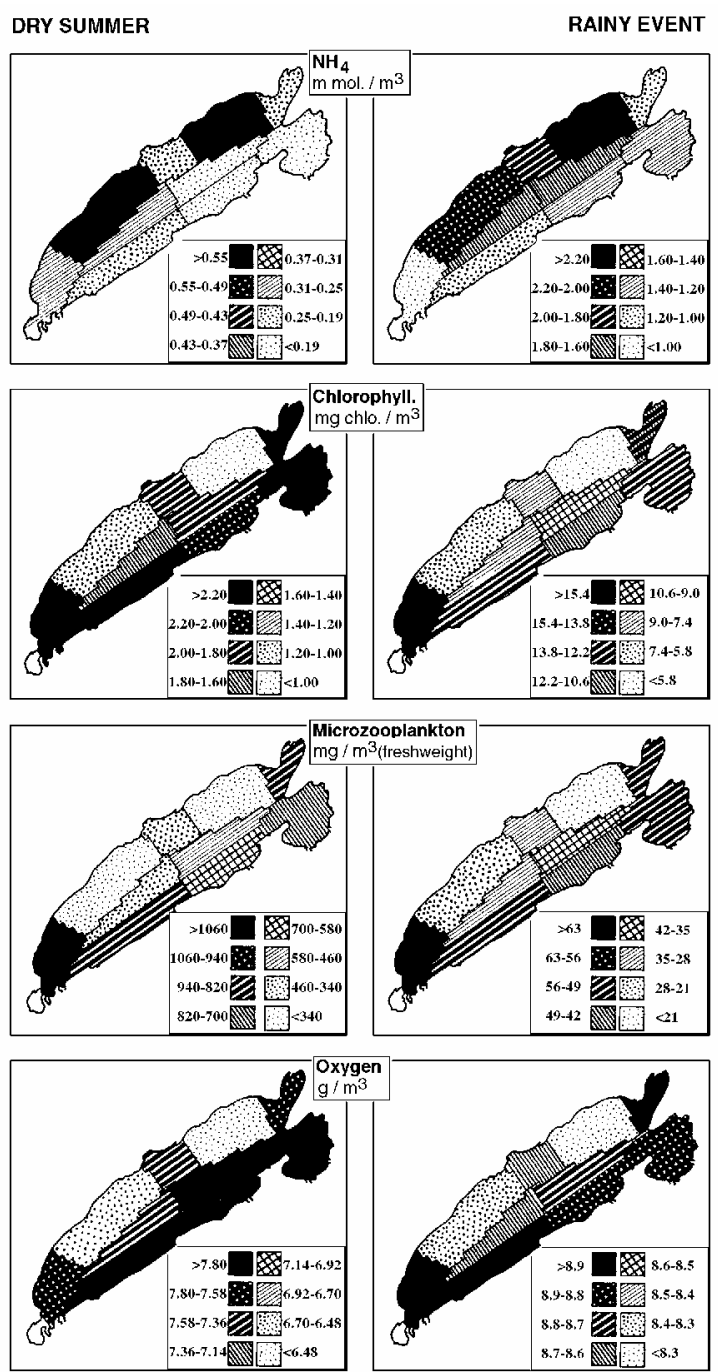

\section{$\underline{\text { Sensivity analysis of parameters }}$}

As this is the first step of the Thau lagoon modelling, it is judiceous to analyse the impact of all the parameters on the simulation results. Each parameter is $+10 \%$ or $-10 \%$ modified and the results of each run is analysed, using a sensivity index to calculate the variation of each variable for $1 \%$ variation of the parameter : IS $=\left(\frac{100}{p}\right) \times \frac{1}{n} \times \sum_{i=1}^{n} \frac{\left|X_{i}-X_{i}^{t}\right|}{X_{i}^{t}}$

With $\mathrm{p}$ the $\%$ of the parameter variation ( + or $-10 \%$ ), $\mathrm{n}$ the day number simulated (365), $\mathrm{X}_{\mathrm{i}}$ the new variable value and $\mathrm{X}_{\mathrm{i}}^{\mathrm{t}}$ the 1993 year variable value. Mean of $+10 \%$ and $-10 \%$ IS is calculated. The result is also averaged over the 10 water boxes.

Figure 6 shows the sensivity results for the water state variables. Parameters giving less than $1 \%$ variation for all the variables are not shown $\left(\right.$ nit $_{0}, \psi P N, d_{P N}, I_{o p t M P}, d_{M P}$, excrm ${ }_{\text {inMiZ, }}$, death $_{\text {maxMiz, }}$ Phy ${ }_{0 M e z}$, excr\% ${ }_{M e z}, K_{\min }, K_{\text {nit }}$, denit ${ }_{0}$, effO ${ }_{\text {Ndet }}$, QPS, rphy, rzoo). Oxygen is also not represented as there is less than $1 \%$ variation for all parameters. 
Figure 6 : Average of the sensivity analysis results for water boxes for each state variable
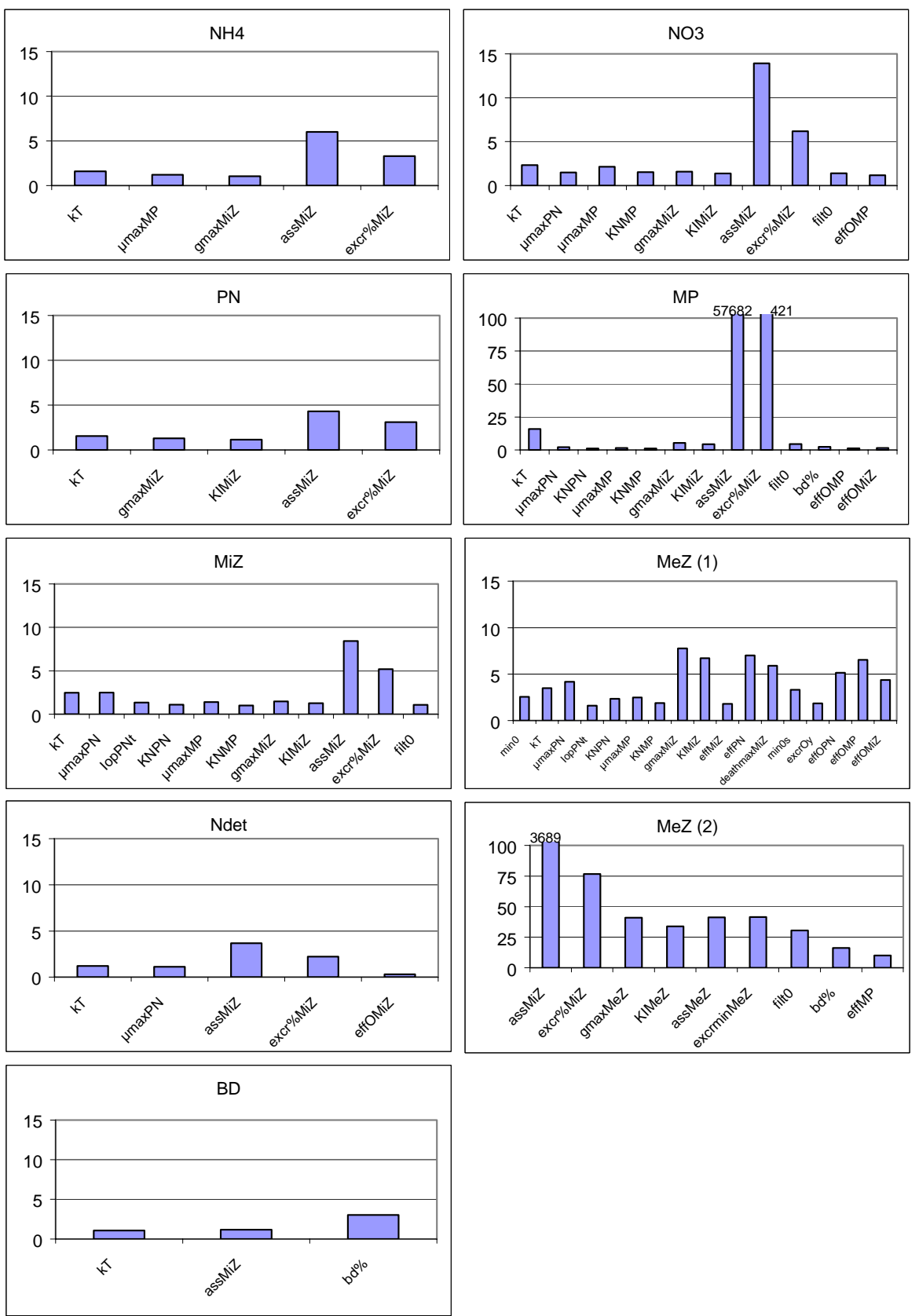

First seeing is that microphytoplankton and mesozooplankton are the most sensible variables in the model. In fact, 13 parameters modify microphytoplankton and 26 mesozooplankton, for more than $1 \%$. Furthermore, microphytoplankton and mesozooplankton are highly changed by the two parameter, assMiZ and excr\%MiZ.

It is a fact in this kind of model that the higher trophic levels, not controlled by other predators, are often very sensible and not well modelled. This is confirmed by the sensivity results as well as the mesozooplankton evolution along the year. In conclusion for that trophic level, a serious investigation in parameters and processes should be undertook with in situ data (Lam Hoai, pers. com.). As mesozooplankton directly control the microphytoplankton, that may explain the high sensivity of this variable even if the involved parameters are microphytoplankton physiological parameters (assimilation and excretion). Whatever it would be also necessary to verify these 
parameters and the chosen equations for these processes with experimental studies (Vaquer, com. pers.).

Microzooplankton and $\mathrm{NO}_{3}$ are sensible for respectively 11 and 10 parameters for more than $1 \%$. This can be explained by the fact that microzooplankton is grazed by mesozooplankton and $\mathrm{NO}_{3}$ is assimilated more by microphytoplankton, which are sensible variables. In fact, $\mathrm{NH}_{4}$ and piconanophytoplankton are much less influenced .

Detritic nitrogen, biodeposits and oxygen are stable considering parameter variations.

In conclusion to this sensivity analysis, it will be necessary to adjust with experimental studies the processes governing microzooplankton as 2 parameters are very sensible (Collos, pers. com.) and to better calibrate mesozooplankton evolution.

\section{Discussion}

\section{Origin of nitrogen in the lagoon}

The difference between the simulation of nitrate and ammonium along the year can be explained by the origin of dissolved nitrogen in the ecosystem (Figure 7). This figure shows the different simulated fluxes of nitrogen production for the shellfish areas (Oy), for the non shellfish area (Lag-Oy) and for the whole lagoon (Thau) in two seasonal cases, dry summer and rainy automn. Nitrate production corresponds to watershed inputs and nitrification, the other fluxes correspond to ammonium production.

Figure 7 : Dissolved nitrogen fluxes in the model (in mgN.m-2.d $\mathrm{d}^{-1}$ ) for the the oyster areas (Oy), the rest of the lagoon (Oy-Lag) and the whole lagoon (Thau). For two different meteorological cases, dry summer and rainy event.
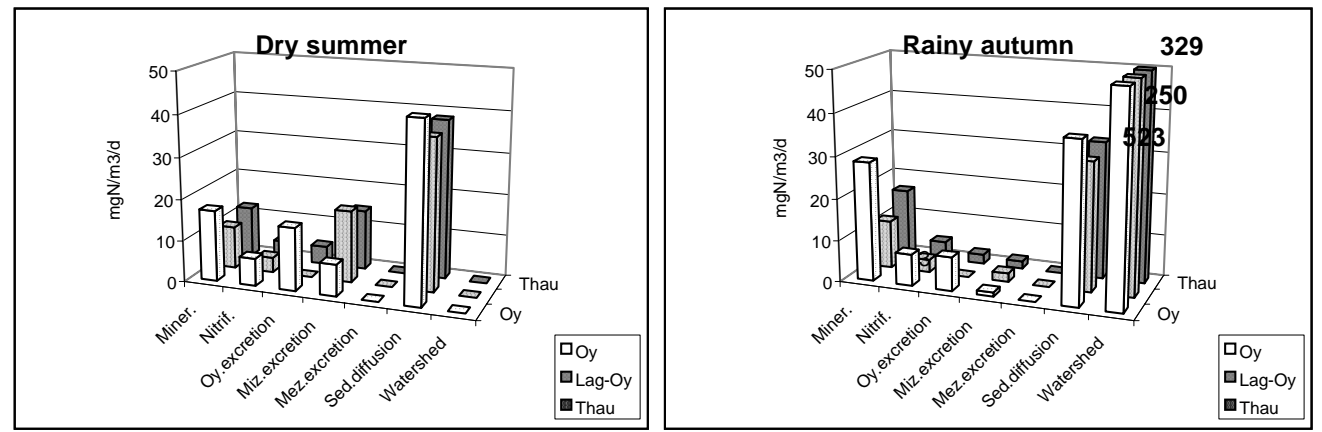

First, it appears that the bigger inputs are the watershed inputs during autumn. This process is responsible for the high level of nitrate observed in the simulation. Nitrate inputs reach for the whole lagoon $329 \mathrm{mgN} \cdot \mathrm{m}^{-2} \cdot \mathrm{d}^{-1}$ in autumn. Compared to this flux, nitrate production by nitrification inside the lagoon, which accounts for $4 \mathrm{mgN} \cdot \mathrm{m}^{-2} \cdot \mathrm{d}^{-1}$, is negligible in autumn and still low in summer. So, for nitrate, the external flux is then much more important than the internal flux.

Ammonium feature is different. Several fluxes contribute to ammonium production but all of them belong to internal processes (i.e. recycling of nitrogeneous material). In fact we ignore ammonium watershed inputs but these are presumed little. In the model sediment release is the major process of internal recycling, reaching $38 \mathrm{mgN} \cdot \mathrm{m}^{-2} \cdot \mathrm{d}^{-1}$ in summer. The role of sediment as a source of nitrogen is a characteristic of coastal areas with shallow waters (Pomeroy et al., 1965 ; Zeitschell, 1980). This result is compared to in situ measurements with benthic bell jars (Mazouni, 1995). Simulated fluxes extend from $31 \mathrm{mg} \cdot \mathrm{m}^{-2} \cdot \mathrm{d}^{-1}$ outside the shellfish area to $43 \mathrm{mg} \cdot \mathrm{m}^{-2} \cdot \mathrm{d}^{-1}$ inside. Measurements show a greater variability from $-10.8 \mathrm{mg} \cdot \mathrm{m}^{-2} \cdot \mathrm{d}^{-1}$ to $216 \mathrm{mg} \cdot \mathrm{m}^{-2} \cdot \mathrm{d}^{-1}$ (Mazouni et al., 1997). The negative value is due to an uptake of ammonium by a high biomass of macrofauna which was a non common situation. As the model does not consider this compartment, it can not be reproduced. The highest measured values were correlated to the case of bottom hypoxia. So considering the mean measured values $\left(43.2 \mathrm{mg} \cdot \mathrm{m}^{-2} \cdot \mathrm{d}^{-1}\right.$ in the oyster culture area and $36 \mathrm{mg} \cdot \mathrm{m}^{-2} \cdot \mathrm{d}^{-1}$ 
in the rest of the lagoon), simulation of sediment release fluxes, due to sediment mineralization and nitrification, is correct.

Mineralization of organic matter in the water column is the second important process of nitrogen cycling in the lagoon, reaching $16 \mathrm{mgN} \cdot \mathrm{m}^{-2} \cdot \mathrm{d}^{-1}$ in automn for the whole lagoon in the model.

If the mesozooplankton excretion is negligible as the excretion coefficient and the simulated biomass are low, the microzooplankton excretion reaches $15 \mathrm{mgN} \cdot \mathrm{m}^{-2} \cdot \mathrm{d}^{-1}$ in summer.

Oysters excretion, which occurs only in the oysters farming areas is higher in summer reaching $15 \mathrm{mgN} \cdot \mathrm{m}^{-2} \cdot \mathrm{d}^{-1}$. This process is highly correlated with temperature (Mazouni et al., 1998). This simulated flux is calculated for the total shellfish area. As only $10 \%$ of this area correspond to the filter feeders, we can compare the simulated flux*10 with measurements of ammonium production by metabolic enclosures for the same year, that is for summer, a range from 124 to $1152 \mathrm{mgN} \cdot \mathrm{m}^{-2} \cdot \mathrm{d}^{-1}$ depending of the localization (Mazouni et al.,1998). Keeping in mind that the model gives only the oyster excretion flux whereas the measurements include all processes hapenning into the enclosure (major one being oyster excretion but also zooplankton excretion, mineralization), the calculated model fluxes are similar to the measurements.

\section{$\underline{\text { New and recycled primary production }}$}

In summer, dissolved nitrogen production is dominated by ammonium flux. Growing on the ammonium fluxe, piconanophytoplankton are responsible for the regenerated primary production, while, in autumn, microphytoplankton, assimilating nitrate, are responsible for the new primary production. In summer, as there is no external input, primary production corresponds to regenerated primary production and reaches $10 \mathrm{mgN} \cdot \mathrm{m}^{-2} \cdot \mathrm{d}^{-1}$ for the whole lagoon $(90 \%$ correspond to piconanophytoplankton production). On the contrary, in the 1993 rainy autumn, new primary production, due to microphytoplankton bloom, is the most important, reaching 75 mgN.m ${ }^{-2} \cdot \mathrm{d}^{-1}$ for the whole lagoon. 1993 primary production measurements show values between 10 and $20 \mu \mathrm{molC} . \mathrm{l}^{-1} \cdot \mathrm{h}^{-1}$ (Fouilland et al., 1995) which can be converted to 42 to $84 \mathrm{mgN} \cdot \mathrm{m}^{-2} \cdot \mathrm{d}^{-1}$. Primary production model results are in the data range but conversions applied to data must be taken with care. Following these results, simulation shows that the Thau lagoon has two different behaviors : as an open system depending on watershed inputs with new primary production or as a closed system during dry season with internal nitrogen cycling and a regenerated primary production. For the 1993 year, in the whole lagoon, simulation gives $31 \mathrm{gNm}^{-2}$ for regenerated primary production and $20 \mathrm{gNm}^{-2}$ for new primary production. This can be compared to the total annual primary production of $60.44 \mathrm{gNm}^{-2}$ estimated from data (Vaquer, data not published).

\section{$\underline{\text { Impact of shellfish cultivation }}$}

Spatial distribution of the simulated variables has shown the differences between shellfish boxes and the rest of the lagoon. In the shellfish areas, ammonium concentrations are higher while concentrations of phytoplankton, zooplankton and oxygen are smaller. This is directly related to the oyster influence. These organisms take up particulate organic matter (such as phytoplankton and zooplankton), consume oxygen and release ammonium via direct excretion. Moreover, as written before, sediment release is higher in the shellfish area because of the high level of organic matter in the sediment produced by the oyster biodeposition. Water mineralization is also more effective in the shellfish boxes with a mean autumn value of $29 \mathrm{mgN} \cdot \mathrm{m}^{-2} \cdot \mathrm{d}^{-1}$ against $12 \mathrm{mgN} \cdot \mathrm{m}^{-2} \cdot \mathrm{d}^{-1}$ in the rest of the lagoon (Figure 7). This can be explained by biodeposition which enhance organic matter in the water column, even if the biodeposits fall to the sediment. On the contrary, the model shows that microzooplankton excretion is higher outside the cultivated areas. This is because microzooplankton, filtered by the oysters, has a smaller biomass in the shellfish areas (Lam Hoai et al., 1997).

Simulation of oyster particulate nitrogen uptake, simulation gives values ranging from $102 \mathrm{mgN} \cdot \mathrm{m}^{-2} \cdot \mathrm{d}^{-1}$ in summer to $343 \mathrm{mgN} \cdot \mathrm{m}^{-2} \cdot \mathrm{d}^{-1}$ during autumnal blooms, whereas measurements give values between $20.9 \mathrm{mgN} \cdot \mathrm{m}^{-2} \cdot \mathrm{d}^{-1}$ in winter to $270 \mathrm{mgN} \cdot \mathrm{m}^{-2} \cdot \mathrm{d}^{-1}$ in summer for the year 1992 (Mazouni, 1995). Considering that 1992 primary production was higher in summer than in 1993 and that autumn 1993 was exeptionally, rainy not as 1992, we can probably conclude that the simulated fluxes are in accordance with the range of the measured fluxes. In summer, pico-nanophytoplankton are the major prey for oyster in the model, reaching $93 \%$ of the total filtration. This agrees with an higher retention efficiency measeured for the assemblage of 
filter-feeding organisms present on the oyster ropes than for isolated oysters, especially for little phytoplankton species (Mazouni et al., 1998). Simulated oyster filtration on microphytoplankton biomass is low in summer as microphytoplankton biomass is negligible but is the main process (55 $\%$ of total filtration) during autumnal bloom.

In the whole lagoon, in summer, results of the model show that pico-nanophytoplankton filtration by oysters equals microzooplankton predation $\left(28 \mathrm{mgN} \cdot \mathrm{m}^{-2} \cdot \mathrm{d}^{-1}\right)$. However, in autumn when oyster filtration is halved $\left(14 \mathrm{mgN} \cdot \mathrm{m}^{-2} \cdot \mathrm{d}^{-1}\right)$ microzooplankton predation is fourteen times less important $\left(2 \mathrm{mgN} \cdot \mathrm{m}^{-2} \cdot \mathrm{d}^{-1}\right)$, microzooplankton biomass being lower. Mesozooplankton impact is negligible as its biomass is low in the model. Integrated over the year, total predation on piconanophytoplankton is $16 \mathrm{gNm}^{-2}$, with $44 \%$ due to microzooplankton and $56 \%$ to oysters. For microphytoplankton predation is due to oysters and equals $7 \mathrm{gNm}^{-2}$ per year. Total predation on phytoplankton corresponds to $52 \%$ of the regenerated primary production and $32 \%$ of the new primary production.

In order to test the impact of oyster biomass on the ecosystem, the oyster biomass has been halved. Simulated phytoplankton show higher concentrations reaching 10 to $20 \mathrm{mg}^{\text {Chloa.m }}{ }^{-}$ ${ }^{3}$ (Figure 8). In fact, reducing oyster biomass in the model decreases the oyster filtration on phytoplankton, which is half of the precedent estimation. Increasing phytoplankton biomass and reducing oyster filtration is also responsible for the higher simulated zooplankton biomass. Piconanophytoplankton primary production is $24 \%$ enhanced and for microphytoplankton primary production is $20 \%$ enhanced. This is the combined result of oyster predation reduction, of zooplankton predation increase (especially mesozooplankton) and of the reduction in ammonium regeneration by oyster excretion. Furthermore the oyster biomass reduction modifies the succession and the dominance of the two populations of phytoplankton as well as zooplankton. In summer, microphytoplankton and piconanophytoplankton both are growing.

In conclusion, the influence of oyster biomass is quantitatively and qualitatively important on the Thau lagon ecosystem behavior. At the moment, further investigations are developped on the filter-feeders impact on the ecosystem as to possibly model the filter-feeders evolution joined with the ecosystem model.

Figure 8 : Phytoplankton simulation when oyster biomass is halved

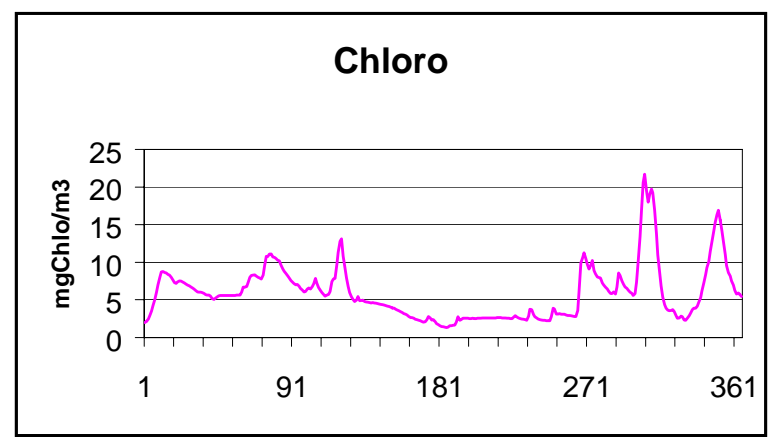

\section{$\underline{\text { Sensitivity to the watershed inputs }}$}

As well as we have studied the oyster biomass influence on the ecosystem, we can try to evaluate the importance of the watershed inputs by running the model with half nitrogen inputs. Results show that simulated $\mathrm{NO}_{3}$ is lowered in the lagoon as well as microphytoplankton and mesozooplankton (figure 9). Annual primary production is then lowered, from $40 \%$ for microphytoplankton production to $15 \%$ for piconanophytoplankton production. Nitrogenous inputs, in fact, is an enrichment factor for the lagoon. They act particularly on new production but also interfere with regenerated primary production as regenerated primary production corresponds to the ammonium regeneration inside the lagoon which a part comes from new production remineralization. By the extreme, if nitrogen inputs to the Thau lagoon stopped, at least, the lagoon would not be no aymore productive. 
Even if the oyster biomass is not modeled, we can conclude that reducing nitrogen inputs interferes with oyster production, as oyster predation on phytoplankton is halved. So, nitrogen inputs from watershed and oyster cultivated biomass both influence the productivity of the Thau lagoon and interact each other.

This analysis on watershed inputs should be pursued in describing the inputs with more details like nitrate and ammonium distinction, origin and situation of the loadings (industrial activities, urban wastes, agriculture loadings...) and relation with meteorological events. This will be the next step to study the real impact of the watershed on the lagoon ecosystem and to forecast the impact of modified activity on the ecological status of the lagoon.

Figure 9 : Nitrate, Phytoplankton and Zooplankton simulation when watershed inputs are halved.
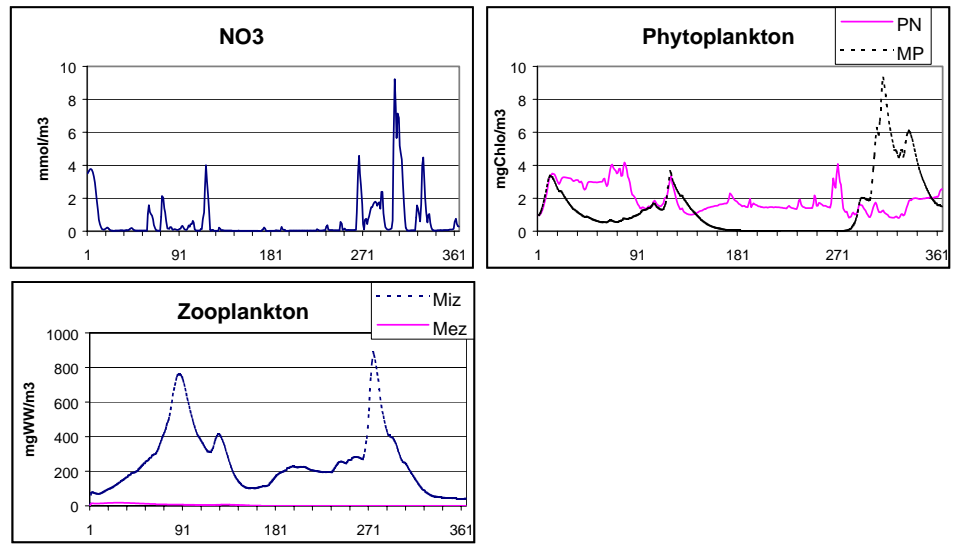

\section{Oxygen sensibility and dystrophic events}

Figure 10 shows the oxygen consumption modelled fluxes in the water column for the two seasons. Apart from benthic demand, mineralization in the water column is the major process, reaching $2.7 \mathrm{gO}_{2} \cdot \mathrm{m}^{-2} \cdot \mathrm{d}^{-1}$ in automn for the whole lagoon. This process is greater in the shellfish area because of the biodeposits mineralization. In situ measurements of oxygen fluxes by metabolic enclosures in sumer 1993 give an oxygen consumption varying from 15 to $69 \mathrm{gO}_{2} \cdot \mathrm{m}^{-2} \cdot \mathrm{d}^{-}$ ${ }^{1}$, depending on the geographic localization of oysters (Mazouni, 1995). These data include all the oxygen processes in the metabolic enclosures : oyster plus epibiota respiration, phytoplankton and zooplankton respiration, organic matter mineralization, nitrification and also phytoplankton or epiflora photosynthesis. We can add these modelled fluxes, keeping in mind that oysters fluxes correspond to $10 \%$ of the shellfish area, in order to compare the sum that is $6 \mathrm{gO}_{2} \cdot \mathrm{m}^{-2} \cdot \mathrm{d}^{-1}$ in summer or $19.1 \mathrm{gO}_{2} \cdot \mathrm{m}^{-2} \cdot \mathrm{d}^{-1}$ in autumn to data. The oxygen modelled fluxes are below those measured. Some explanations could be undertook. In the above hypothesis we consider the same oxygen flux for mineralization inside and outside the oyster assemblages but inside the organic matter concentration is greater because of the oyster biodeposition. So the modelled fluxes are probably underestimated compared to the data. Further experimentations should be drawn to evaluate the respective role of oysters and epifauna on the environment. 
Figure 10 : Oxygen fluxes (g.m-2.d-1) in summer for the the oyster areas (Oy), the rest of the lagoon (Oy-Lag) and the whole lagoon
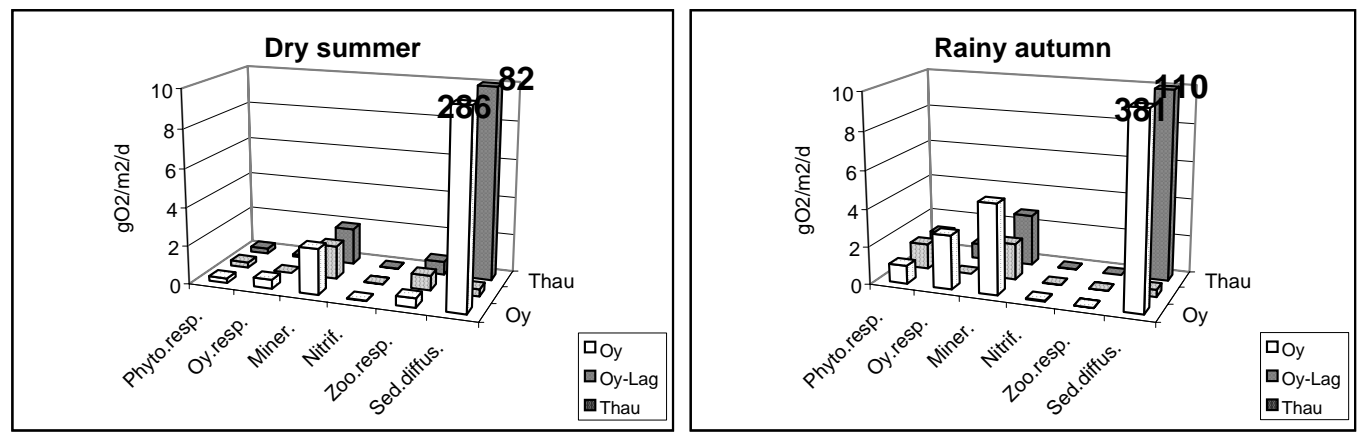

Oxygen benthic demand is the major process involved in oxygen water concentration. The model shows high oxygen fluxes in the shellfish area, about 300 times higher than in the rest of the lagoon. In fact, oyster cultivation produces biodeposits enhancing benthic activity (Grenz et al., 1990 ; Kautsky and Evans, 1987). This explains the difference of sediment oxygen concentration in the oysters areas and outside. It is difficult to compare these modeled fluxes to benthic fluxes measured by bell jars for several reasons. One is that the model does not take into account the production or consommation of oxygen in the sediment by algae or fauna, it only includes the diffusion of oxygen that is consummed by mineralization and nitrification. Further improvments could be made by including the influence of macrophytes and microphytobenthos (Barranguet and Alliot, 1995 ; Gerbal and Verlaque, 1995), which are neglected at the moment in the model.

Following this study on the oxygen budget, it appears that shellfish areas are a sensible area for the oxygen depletion, principally because of the high oxygen benthic demand sediment. With further developments, the model will be applied to understand the environmental conditions leading to anoxia crisis.

\section{Conclusion}

The model presented in this study is the first stage of a more general lagoon ecosystem model. The major variables implied in the ecosystem evolution have been determined as well as the impact of forcing functions. It has been shown that it is necessary to simulate both the new and the regenerated primary production to understand the annual primary production. Each one uses a different trophic link, nitrate - diatoms - mesozooplankton for new primary production, highly controlled by the watershed inputs, and ammonium - piconanophytoplankton - microzooplankton, based on internal nitrogen cycling. Further improvements should be made considering more detailed watershed inputs, as nitrate or ammonium and with spatial and temporal variability. Simulating the origin of the inputs, agriculture inputs, leaching with rain, industrial inputs, domestic sewage should allow to model the impact of each economic actvity on the lagoon system. Moreover, the atmospheric inputs, the inputs from ground water and exchanges with the sea should be evaluated.

Another point of the Thau lagoon originality is oyster production. This affects greatly the nutrient cycle and the oxygen budget. To improve the knowledge of the influence of the shellfish farming on the system, the model should take into account the exportation of nitrogen by harvesting. Experiments and formulation of the relative role of oysters and biofouling should improve the model.

Finally, to improve the global ecosystem model, the macrophytes compartment should be developed, as it reacts with the nitrogen and oxygen evolution.

Validating this model on the Thau lagoon on several years and different meteorological cases will be the next step then, this model would be applied to other mediterranean lagoons as to compare the response and the specificities of each ecosystem. 


\section{References}

Amanieu M., Legendre P., Trousselier P., Frisoni G.F., 1989. Le programme ECOTHAU: théorie, écologie et base de la modélisation, Océanol. Acta, 12 : 189-199.

Aminot A., Chaussepied M., 1983. Manuel des méthodes d'analyses chimiques (RNO). CNEXO, 395 pp.

Azam F., Fenchel T., Field J.G., Gray J.S., Meyer-Reil L.A., Tingstad F. 1983. The ecological role of water-column microbes in the sea. Mar. Ecol. Prog. Ser., 10 : 257 - 263.

Bacher C., Bioteau H., Chapelle A., 1995. Modelling the impact of a ciltivated oyster population on the nitrogen dynamics: the Thau lgoon case (France). Ophelia, $42: 29$-5 4.

Bacher C., Millet B., Vaquer A, 1997. Modélisation de l'impact des mollusques cultivés sur la biomasse phytoplanctonique de l'étang de Thau (France). Comptes Rendus de l'Academie des Sciences, 320 : 73-81.

Bacher C., Chapelle A. Modelling the Thau lagoon ecosystem, a synthesis. Oceanologica acta, accepted.

Barranguet C., Alliot E., 1995. Variations spatio-temporelles des flux benthiques (oxygène et ammonium) et de la biomasse microphytobenthique dans la zone conchylicole de l'Etang de Thau (France). J. Rech. Océanogr., 20 : 15 - 26.

Butler E.I., Corner E.D., Marshall S.M., 1969. On the nutrition and metabolism of zooplankton. VI. Feeding efficiency of Calanus in terms of nitrogen and phosphorus. J. Mar. Biol. Ass. UK, 49 : 977 - 1001.

Chapelle A., 1995. A preliminary model of nutrient cycling in sediments of a Mediterranean lagoon. Ecol. Model., 80 : 131- 147.

Chapelle A., Mesnage V., Mazouni N., Deslous-Paoli J.M., Picot B., 1994. Modélisation des cycles de l'azote et du phosphore dans les sédiments d'une lagune soumise à une exploitation conchylicole. Océanol. Acta, 17 : 609-620.

Chrétiennot-Dinet M.J., Courties C., Vaquer A., Neveux J., Claustre H., Lautier J., Machado C., 1995. A new marine picoeucaryote : Ostreococcus tauri gen. et sp. nov. (Chlorophyta, Prasinophyceae). Phycologia, 34 : 285-292.

Cirillo J., 1994 - Microzooplancton de deux sites dans une lagune nord-méditerranéenne (Etang de Thau): étude de peuplement par analyse d’image. Suivi journalier Mars 1994). Mém.DESS.Univ.Corse - Lab.Hydrobiol.mar.cont., Univ.Montpellier II, Montpellier: 68 p.

Collos Y., Vaquer A., Slawyk G., Garcia N., Souchu P., 1997. Variability in nitrate uptake of phytoplankton communities a Mediterranean coastal lagoon. Estuar. Coastal and Shelf Science, 44 : 369 - 375.

Conover R.J., 1966. Assimilation of organic matter by zooplankton. Limnol. Oceanogr,. 11 : 338 354.

Courties C., Vaquer A., Troussellier M., Lautier J., Chrétiennot-Dinet M.J., Neveux J., Machado C., 1994. Smallest eukaryotic organism. Nature, $370: 255$

Deslous-Paoli J.-M., Mazouni N., Souchu P., Landrein S., Pichot P. and Juge C., 1993. Oyster farming impact on the environment of a mediterranean lagoon (Thau). Prelimanary results of the Oxythau programme. In R.F. Dame (ed.) : Bivalve filter-feeders in estuarine and coastal ecosystem processes. NATO ASI Series, 33 : 519 - 520

Deslous-Paoli J.-M. (ed.), 1995. Programme OXYTHAU. Le bassin de Thau: relation milieuressources dans les secteurs conchylicoles. Importance des mécanismes d'échanges verticaux. 1991 - 1995, 26pp.

Deslous-Paoli J.-M., Vaquer A., 1995 (resp.). Interactions filtreurs-microorganismes : apports à l'analyse des systèmes et à la gestion des milieux côtiers. Compte-rendu d'activité de l'URM 5 pour 1992 - 1995.

Eppley R.W., Rogers J.B., Mc Carthy J.J., Sournia A., 1971. Light/dark periodicity in nitrogen assimilation of the marine phytoplankters Skeletonema costatum and Coccolithus huxley in Nlimitant chemostat culture. J. Phycol., 7 : 150-154.

Eppley R.W., 1972. Temperature and phytoplankton growth in the sea. Fishery Bulletin, 70 : 1063 - 1085. 
Fouilland E., Vaquer A., Descolas-Gros C., 1995. Annual variations in CO2 assimilation and primary production measurements in a mediterranean lagoon (Thau lagoon, France). In Phothosynthesis : from light to biosphere, P. Mathis ed., 5: 873-876.

Frisoni G.F., Cepja A.M., 1989. La malaïgue dans les étangs littoraux du Languedoc-Roussillon. Report Cepralmar, 48 pp.

Gerbal M., Verlaque M., 1995. Macrophytobenthos de substrat meuble de l'étang de Thau (France, Méditerranée) et facteurs environnementaux associés. Oceanol. acta, 18 : 557 - 571.

Goldman J.C., Caron D.A. 1985. Experimental studies on an omnivorous microflagellate. Implications for grazing and nutrient regeneration in the marine microbial food chain. Deep Sea Res., 32 : 889 - 915.

Grenz C., Hernin M.N., Baudinet D., Daumas R, 1990. In situ biochemical and bacterial variation of sediments enriched with mussel deposits. Hydrobiologia, $207: 153$ - 160.

Hamon P-Y., Tournier H., 1990. Etude des stocks de mollusques élevés dans l'étang de Thau de 1981 à 1987. Rapp. Ifremer Sète, 121p.

Henriksen K., Kemp W.M., 1988. Nitrification in estuarine and coastal marine sediments. In T.H. Blakburn and Sørensen (editors), Nitrogen Cycling in Coastal Marine Environment, Wiley and sons, New York, 207 - 249.

Ivlev V.S., 1955. Experimental Ecology of the Feeing Fishes. Yale University Press, Nw Haven.

Jarry V., M. Fiala, G.-F. Frisoni, G. Jacques; J. Neveux, M. Panouse (1990). The spatial distribution of phytoplankton in a Mediterranean lagoon (Etang de Thau). Oceanologica Acta, 13 : 503-512.

Jouffre D., T. Lam-Hoai, B. Millet, M. Amanieu (1991). Structuration spatiale des peuplements zooplanctoniques et fonctinnement hydrodynamique en milieu lagunaire. Oceanologica Acta, 14 :, 489-504.

Kautsky N., Evans S., 1987. Role of biodeposition by Mytilus edulis in the circulation of matter and nutrients in a Baltic coastal ecosystem. Mar. Ecol. Prog. Ser., 38 : 201-212.

Lam Hoai T., Rougier C., Lasserre G., 1997. Tintinnids and rotifers in a northern Mediterranean coastal lagoon. Structural diversity and function through biomass estimations. Mar. Ecol. Prog. Ser., 152 : 13-25.

Mazouni N., 1995. . Influence des élevages ostréicoles sur le fonctionnement d'un écosystème lagunaire médieterranéen. Etude in situ de l'influence des filtreurs (coquillages et épibiontes) sur les flux de matières particulaires et dissoutes. Thèse Un. Aix-Marseille II.

Mazouni N., Gaertner J-C., Deslous-Paoli J.M., Landrein S.,Geringer d’Oedenberg M., 1996. Nutrient and oxygen exchanges at the water-sediment interface in a shellfish farming lagoon (Thau, France). J. exp. Mar. Biol. Ecol., 205 :, 91-113.

Mazouni N., Gaertner J-C., Deslous-Paoli J.M. 1998. Influence of oyster culture on the water column characteristics in a coastal lagoon (Thau, France). Hydrobiologia, 373/374 : 149-56.

Mesnage V., 1994. Contribution à l'étude de la mobilité des formes de phosphates à l'interface eau-sédiment dans des écosystèmes lagunaires. Thèse de doctorat de l'Université de Montpellier I, $252 \mathrm{pp}$.

Mesnage V., Deslous-Paoli J.M, Picot B., Landrein S., Juge C., 1993. L'eau interstitielle du sédiment d'une lagune méditerranéenne : comparaison de méthodes de prélèvements. Proceedings du congrès "séminaire européen sur les technologies marines". Santa Margherita (Itakie) 4-6 mars 1993.

Ménesguen A., 1991. "ELISE", an interactive software for modelling complex aquatic ecosystems. Dans Computer Modelling in Ocean Engineering 91, Arcilla et al (eds.), Balkema, Rotterdam, 87-94.

Millet B., 1989. Fonctionnement hydrodynamique du bassin de Thau. Validation écologique d'un modèle numérique de circulation (programme Ecothau). Oceanol. acta, 12 : 37- 46.

Nakanashi H., Ukita M.,. Kawai Y, 1986. Study on the modelling of the behavior of phosphorus released from sediments. Ecol. Model., 31 : 105 - 123.

Pichot P., Ximenes M.C., Deslous-Paoli J.-M., Juge C., 1994. Bilan de l'azote et du phosphore dans le système lagune-bassin versant de Thau. Contrat Plan Etat-Région Languedoc-Roussillon, Ifremer R.Int. DEL/94.11/Sète, 84pp.

Picot B., G. Péna, C. Casemmas, D Bondon., J. Bontoux, 1990. Interpretation of the seasonal variations of nutrients in a mediterranean lagoon: étang de Thau. Hydrobiologia, 207 :, 105-114.

Pomeroy L.R., E.E. Smith, C.M. Grant, 1965. The exchange of phosphate between estuarine water and sediments. Limnol. Oceanogr., $10: 167172$. 
Riley M.J., Stefan H.G., 1988. Minlake : a dynamic lake water quality simulation model. Ecol. Model., 43 : 155 - 182.

Rougier C., Lam Hoai T., 1997 - Biodiversity through two groups of microzooplankton in a coastal lagoon (Etang de Thau, France). Vie et Milieu, 47 : 387-394.

Souchu P., 1997. Shellfish farming and environment : the Thau lagoon study case. Oceanol. acta, accepted..

Souchu P., Gasc A., Collos Y., Vaquer A., Tournier H., Deslous-Paoli J.-M., 1997. Biogeochemical aspects of bottom anoxia in a Mediterranean lagoon. Geochemica acta, submitted. Steele J.H., 1962. Environment control of photosynthesis in the sea. Limnol. Oceanogr., 7 :, 137 150.

Vaulot D., Frisoni G.-F., 1986. Phytoplanktonic productivity and nutrients in five Mediterranean lagoons. Oceanologica acta, 9 : 57 - 63.

Vaquer A., Troussellier M., Courties C., Bibent B., 1996. Standing stock and dynamics of picophytoplankton in the Tau lagoon (northwest Mediterranean coast). Limnol. Oceanogr., 41 :, 1821 - 1828.

Verity P.G. 1985. Grazing, respiration, excretion and growth rates of tintinnids. Limnol. Oceanogr., $30: 1268$ - 1282.

Wen Y.H., Peters R.H. 1994. Empirical models of phosphorus and nitrogen excretion rates by zooplankton. Limnol Oceanogr., 39 :, 1669 - 1679.

Wroblewski, J.S., 1977. A model of phytoplankton plume formation during variable Oregon upwelling. J. Mar. Res., 35 : 357 - 394.

Zeitschell B., 1980. Sediment-water intercation in nutrient dynamics. In Marine benthic dynamics, K.R. Tenore and B.C. Coul (eds.), Univ. South Carolina, Coumbia, 195- 218. 